\title{
Critical Evaluation of ECV304 as a Human Endothelial Cell Model Defined by Genetic Analysis and Functional Responses: A Comparison with the Human Bladder Cancer Derived Epithelial Cell Line T24/83
}

\author{
Julia Brown, Sarah J. Reading, Sarah Jones, Caroline J. Fitchett, John Howl, \\ Ashley Martin, Clare L. Longland, Francesco Michelangeli, Yuri E. Dubrova, and \\ Colin A. Brown
}

Molecular Pharmacology Group (JB, SJ, CJF, JH, AM, CAB), School of Health Sciences, University of Wolverhampton, Liver Sciences Unit (SJR), Kings College, London, The Rayne Institute, London, School of Biochemistry (CLL, FM), University of Birmingham, Edgbaston, Birmingham, and Department of Genetics (YED), University of Leicester, University Road, Leicester, United Kingdom

\begin{abstract}
SUMMARY: Early reports indicated that ECV304 was a spontaneously-transformed line derived from a Japanese human umbilical vein endothelial cells (HUVEC) culture. Many morphological, immunochemical, and genetic studies provided further evidence that ECV304 was a valuable biomedical research tool and could be used to study processes that include angiogenesis in vitro and signal transduction by a variety of $\mathrm{G}$ protein-coupled receptors. However, several distinct differences between ECV304 and HUVEC are now apparent and recent reports have indicated genetic similarity between ECV304 and T24/83, a human bladder cancer cell line. To further assess the utility of ECV304 as a human endothelial cell model, we compared the functional responses of ECV304 and T24/83 to a range of G protein-coupled receptor agonists. We also used DNA fingerprinting to karyotype both ECV304 and T24/83. Both ATP and uridine triphosphate (UTP) stimulated inositol phosphate metabolism in ECV304 without alteration of cAMP levels. Comparative data using selective P2Y receptor agonists indicated that this response, leading to calcium mobilization from intracellular stores, was predominantly mediated by the activation of P2Y, receptors. Similar responses were recorded from both ECV304 and T24/83 cells. ECV304 expressed a relatively high basal activity of NOS that was reduced by L-NAME and stimulated by $\mathrm{P}_{2} \mathrm{Y}_{2}$ receptor agonists. In contrast, $\mathrm{P}_{2} \mathrm{Y}_{2}$ receptor activation did not induce prostaglandin synthesis in ECV304. Both ECV304 and T24/83 express receptors for adenosine, adrenaline, and calcitonin, which stimulate adenylate cyclase. Proliferation of ECV304 and T24/83 cells, measured by the incorporation of $\left[{ }^{3} \mathrm{H}\right]$ thymidine into DNA, was largely serum-independent. This was in contrast to parallel experiments with porcine and bovine aortic endothelial cells that indicated a marked serum-dependent increase in DNA synthesis. Genetic analysis confirmed that ECV304 and T24/83 are identical. ECV304 displays some endothelial characteristics and is useful for the study of receptor pharmacology. However, ECV304 is not of HUVEC origin and is therefore an inappropriate cell line to study endothelial cell biology. (Lab Invest 2000, 80:37-45).
\end{abstract}

7 he control of vascular tone by endothelial cells Many studies have used primary cultures of vascular endothelial cells isolated from a range of tissues and species (eg, Gallery et al, 1991; Spatz et al, 1997; Tokunaga and Watanabe, 1987; Weis et al, 1991; Williams, 1987). However, the isolation and culture of human vascular endothelial cells is associated with a number of specific problems that include a fastidious requirement for exogenous growth factors, mixed populations of cells arising from pooled vessel preparations, and a relatively low proliferative capacity.

Received September 10, 1999.

Address reprint requests to: Dr. Colin A. Brown, Molecular Pharmacology Group, School of Health Sciences, University of Wolverhampton, 62-68 Lichfield Street, Wolverhampton, WV1 1DJ, United Kingdom. Fax: 44 1902321161; 5382@w/v.ac.uk
Thus, the description of ECV304 as a spontaneously transformed cell line from human umbilical vein endothelial cells (HUVEC) represented a potentially significant advance in this area of research (Takahashi et al, 1990). Significantly, ECV304 maintains an apparently typical endothelial morphology in the absence of specific growth factors (Takahashi et al, 1990). Subsequently, numerous studies including morphological, cytochemical, and genetic analyses, further validated ECV304 as an endothelial cell model (reviewed in Takahashi and Sawasaki, 1992). More recently, the ability of ECV304 to exhibit angiogenic behavior when cultured on matrigel has also been reported (Hughes, 1996).

Although ECV304 has proven valuable for many in vitro applications, several distinct differences between ECV304 and HUVEC are apparent and include: lack of expression of the endothelial cell marker von Wille- 
brand Factor (Hughes, 1996; Takahashi et al, 1990); positive expression of the epithelial cell markers cytokeratin 6, 8, 10, 17, 18, and 19 (Hughes, 1996); and expression of calcitonin receptors (Howl et al, 1998). These phenotypic differences have been further substantiated by very recent evidence supplied by the European Collection of Animal Cell Cultures (ECACC) suggesting a genetic similarity between ECV304 and the bladder cancer epithelial cell line T24/83.

In this study we provide important new evidence that ECV304 and T24/83 are genetically identical. Moreover, we have performed a detailed pharmacological and biochemical analysis of receptor expression and function in these cells. We have also compared mitogenic responses in ECV304 and T24/83 with other primary endothelial cell cultures. The results of these investigations demonstrate that ECV304 and T24/83 exhibit a similar phenotype and that some functional responses observed in ECV304 are atypical of endothelial cells. These findings provide important new evidence regarding the suitability of ECV304 as an endothelial cell model.

\section{Results}

\section{Fingerprint Analysis}

Figure 1 shows DNA fingerprints from three different batches of cells all supplied by ECACC. Results clearly show that the ECV304 cells used in our laboratory prior to the controversy over the origin of ECV304 (passage number 175), ECV304 cells obtained recently at passage number 136, and T24/83 cells are genetically identical.

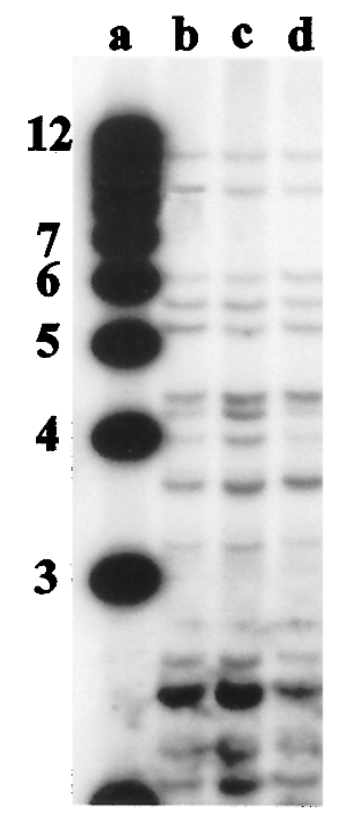

Figure 1.

DNA fingerprints from ECV304 and T24/83 cells. Lane a shows $1 \mathrm{~kb}$ DNA ladder (Gibco). Lanes $b$ and $c$ show two different stocks of ECV304 cells at passage 175 and 136, respectively. Lane $d$ shows results obtained for T24/83 cells. ECV304 and T24/83 cells have the same DNA fingerprint and are therefore genetically identical.

\section{Comparative Pharmacology of P2Y Receptors}

The importance of $\mathrm{P} 2 \mathrm{Y}$ receptors in endothelialmediated control of vascular function is well established (eg, for reviews see Boarder and Hourani 1998; Boarder et al, 1995), with these receptors being linked to the production of nitric oxide and prostacyclin (eg, Bowden et al, 1995; Brown et al, 1996). Therefore we investigated the expression and functional responses of these receptors in ECV304 and T24/83 cells, and compared these responses with those of other endothelial cells in our laboratory.

Figure $2 \mathrm{a}$ shows $\left[{ }^{3} \mathrm{H}\right] \mathrm{Ins}_{1-4}$ accumulation in response to maximal concentrations of ATP, UTP, and 2MeSATP in ECV304 cells and T24/83 cells. The $\mathrm{P}_{2} \mathrm{Y}_{1}$-selective agonist 2MeSATP $(30 \mu \mathrm{M})$ failed to elicit a response in either cell type. Both ATP and UTP were full agonists (Fig. 2b) and responses were dosedependent with mean $\mathrm{EC}_{50}$ values $(n=5)$ of: ATP, $9.9 \pm 4.9 \times 10^{-7} \mathrm{M}$; UTP, $4.48 \pm 0.50 \times 10^{-6} \mathrm{M}$. Further studies with uridine diphosphate (UDP), in the presence of hexokinase to remove contamination from triphosphates (Harden et al, 1997), showed that UDP was unable to mediate any agonist effect under these conditions. Similar experiments with ADP showed this nucleotide to be a weak agonist with an $\mathrm{EC}_{50}$ of $8.94 \pm 3.10 \times 10^{-5} \mathrm{M}(n=3)$ (data not shown). Thus, these results gave a rank order of agonist potency at the ECV304 P2Y receptor of ATP $>$ UTP $>$ ADP $>>$ UDP inactive, 2MeSATP inactive.

\section{Intracellular $\mathrm{Ca}^{2+}$ Mobilization}

All experiments were performed in a $\mathrm{Ca}^{2+}$-free medium containing EGTA (30 mm). As shown in Figure 3a, the P2Y ${ }_{1}$-selective agonist 2MeSATP $(30 \mu \mathrm{M})$ had no effect on cytosolic $\mathrm{Ca}^{2+}$ levels in ECV304 cells. UTP $(300 \mu \mathrm{M})$ induced a rapid rise in cytosolic $\mathrm{Ca}^{2+}$ that peaked in 10 seconds and declined to basal levels in a further 180 seconds (Fig. 3a). Responses to $300 \mu \mathrm{M}$ ATP displayed similar kinetics (Fig. 3b); and $300 \mu \mathrm{M}$ hexokinase-treated UDP elicited no increase in cytosolic $\mathrm{Ca}^{2+}$ (Fig. 3c), whereas $300 \mu \mathrm{M}$ untreated UDP induced a rapid rise in cytosolic $\mathrm{Ca}^{2+}$ to levels similar to those obtained with either UTP or ATP.

\section{Receptors Coupled to Adenylate Cyclase Activation}

Previous studies demonstrated the expression of three pharmacologically distinct receptors in ECV304 able to stimulate cAMP synthesis (Howl et al, 1998). We therefore compared the ability of a similar series of agonists that stimulate cAMP in T24/83 cells. Table 1 shows that adrenaline, calcitonin, and NECA were able to mediate substantial elevations of cAMP over basal levels in both cell lines. ATP and UTP at maximal concentrations did not stimulate CAMP production or inhibit the stimulation mediated by adrenaline.

\section{P2Y Receptor-Induced Release of Vasoactive Compounds}

Nitric Oxide. Figure $4 \mathrm{a}$ shows that both ATP and UTP dose-dependently stimulated the activity of nitric 
A

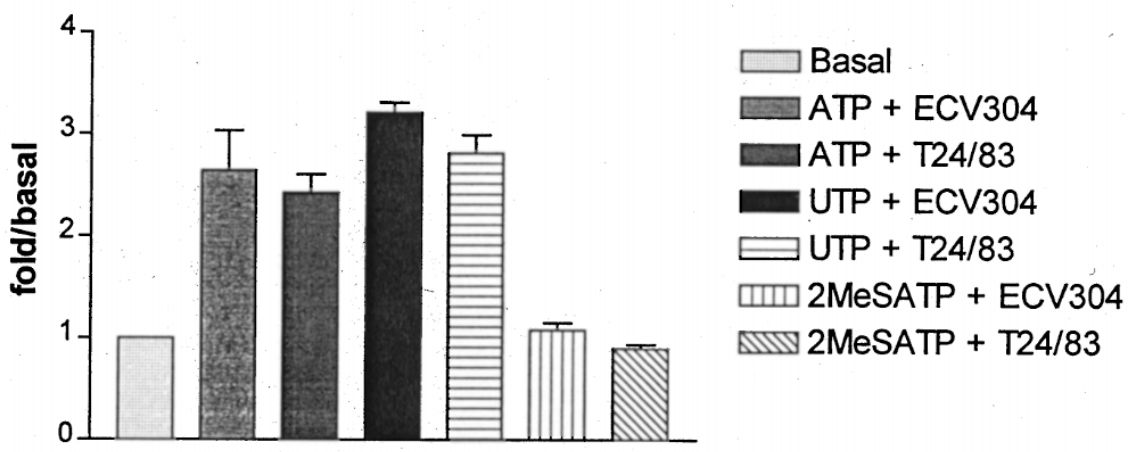

B

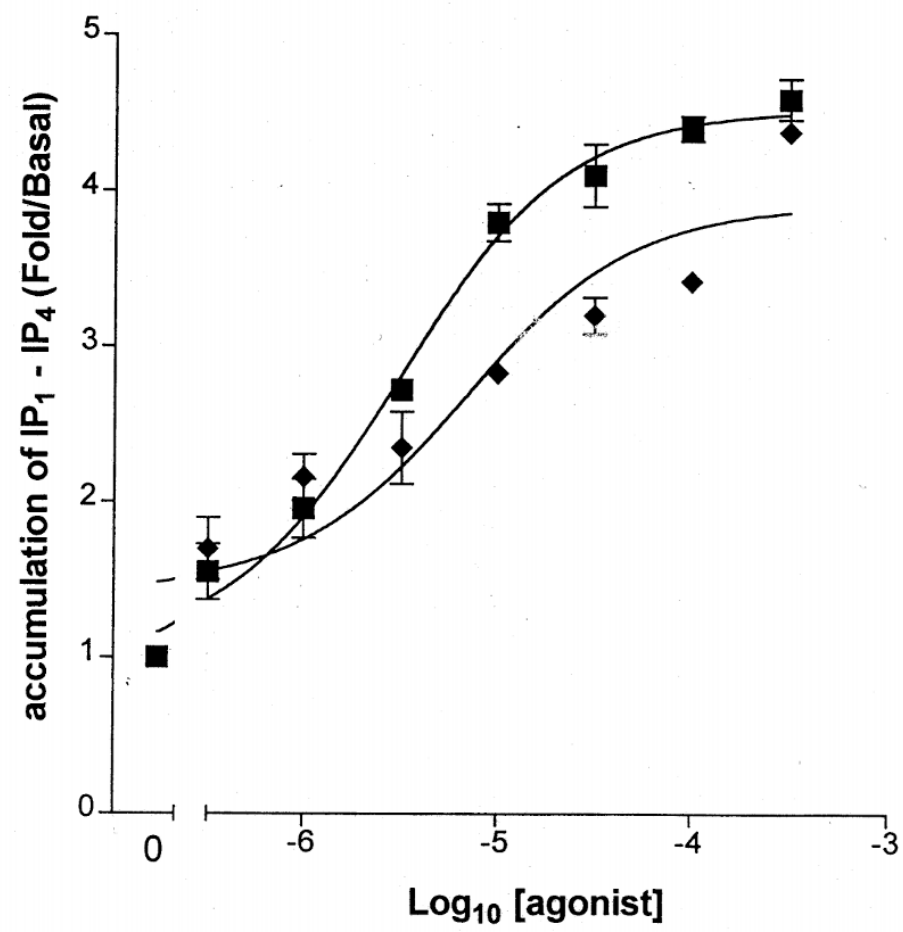

Figure 2.

A, $\left[{ }^{3} \mathrm{H}\right]-$-InsP ${ }_{1-4}$ responses to $100 \mu \mathrm{M}$ ATP, UTP, and $30 \mu \mathrm{m}$ 2MeSATP in ECV304 and T24/83 cells. Similar responses were observed in both cell types with ATP and UTP giving responses of comparable magnitude. 2MeSATP was without effect in either cell type. Data are mean results \pm SEM from three separate experiments, each performed in triplicate. $B$, Dose-dependent accumulation of $\left[{ }^{3} \mathrm{H}\right] \mathrm{ip} \mathrm{p}_{1-4}$ in response to ATP $(\bullet)$ and UTP ( $\left.\mathbf{\square}\right)$ in ECV304 cells. Data are mean results \pm SEM from a representative experiment performed in triplicate.

oxide synthase in ECV304 cells as indicated by the accumulation of $\left[{ }^{3} \mathrm{H}\right]$ citrulline in cell extracts. The $\mathrm{EC}_{50}$ values for ATP and UTP were $5.86 \pm 1.90 \times 10^{-7} \mathrm{M}$ and $5.34 \pm 2.03 \times 10^{-6} \mathrm{M}$, respectively. The maximal stimulation, expressed as increase over basal levels, was $1.80 \pm 0.08$ and $1.83 \pm 0.06$ for $100 \mu \mathrm{M}$ ATP and UTP, respectively. 2MeSATP did not elicit a response at concentrations up to $30 \mu \mathrm{M}$ (data not shown). From these experiments it was evident that there was a high basal turnover of nitric oxide in ECV304 cells that was dose-dependently inhibited by the arginine analog L-NAME with an $\mathrm{IC}_{50}$ value of $7.2 \pm 2.0 \times 10^{-8} \mathrm{M}(n=$ 3) (Fig. 4b). In contrast, BAE cells that express both $\mathrm{P}_{2} \mathrm{Y}_{1}$ and $\mathrm{P}_{2} \mathrm{Y}_{2}$ receptors (Motte et al, 1993; Wilkinson et al, 1994) did not exhibit a high basal turnover of nitric oxide production. When stimulated with $2 \mathrm{Me}-$
SATP and UTP at maximal concentrations, BAE cells accumulated $\left[{ }^{3} \mathrm{H}\right]$ citrulline up to 5 times basal levels (Fig. 4c).

Prostaglandin. Surprisingly UTP $(100 \mu \mathrm{M})$ did not stimulate the release of prostaglandin $\left(\mathrm{PGI}_{2}\right)$ from ECV304 cells as indicated by the lack of accumulation of 6-keto PGF P $_{1 \alpha}$ over a time period of 10 minutes (Fig. 5). In contrast, comparative studies with BAE cells indicated a substantial UTP-induced release of $\mathrm{PGI}_{2}$ that was maximal after 5 minutes (Fig. 5).

\section{Serum-Induced Changes in DNA Synthesis}

Table 2 shows comparative studies of thymidine incorporation in ECV304 and T24/83 cells and porcine and bovine aortic endothelial cells. Subconfluent 
A

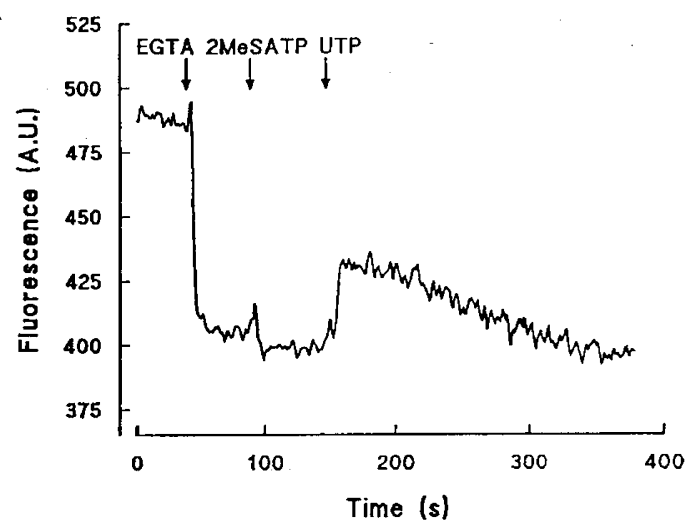

B

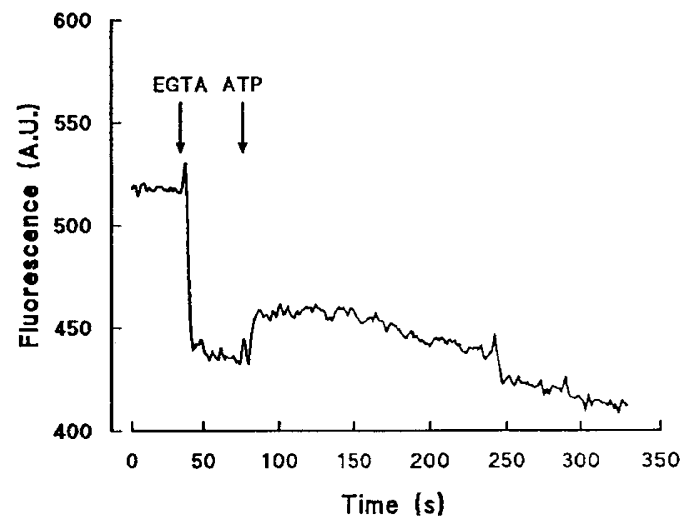

C

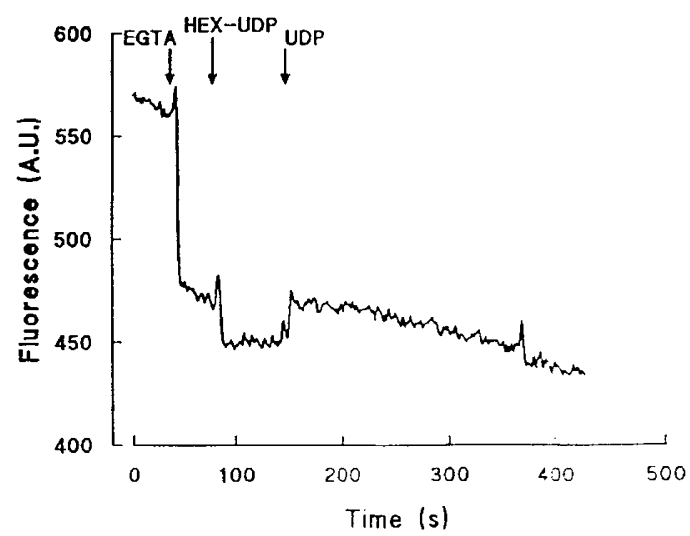

Figure 3.

Results obtained for Fura-2 AM loaded ECV304 cells stimulated with P2Y agonists in the presence of $30 \mathrm{~mm}$ EGTA; $A$, $30 \mu \mathrm{M}$ 2MeSATP followed by 300 $\mu \mathrm{M}$ UTP $(B) 300 \mu \mathrm{m}$ ATP. C, Responses to $300 \mu \mathrm{m}$ hexokinase-treated UDP followed by $300 \mu \mathrm{M}$ UDP.

monolayers of cells were grown in serum-free medium for 24 hours, followed by the addition of serum for 21 hours. Data indicate that addition of serum to the medium of porcine aortic endothelial (PAE) cells and bovine aortic endothelial (BAE) cells resulted in a large incorporation of tritium, up to levels 100 -fold over basal. In contrast, in both ECV304 and T24/83 cultures, there was a large incorporation of tritium into the cells under serum-free conditions that was not significantly changed by the addition of serum (Table 2).
Table 1. cAMP Levels in ECV304 and T24/83 Cells

\begin{tabular}{lcc}
\hline \multicolumn{1}{c}{ Test Compound } & ECV304 & T24/83 \\
\hline Adrenaline & + & + \\
Calcitonin & + & + \\
NECA & + & + \\
ATP & - & - \\
UTP & - & - \\
Adrenaline + UTP & - & ND \\
\hline
\end{tabular}

Ability of various agonists to stimulate CAMP was compared between ECV304 and T24/83 cells. Data are from four separate observations. ND, not determined

\section{Discussion}

ECV304 is widely reported as an immortal endothelial cell line spontaneously transformed from a HUVEC culture in 1985 (Takahashi et al, 1990). Recently however, there has been some controversy regarding the origin of these cells, with the indication that ECV304 is identical to the bladder carcinoma cell line T24/83 (unpublished information supplied by ECACC). In this study we have used genetic analysis and a range of functional assays to determine whether ECV304 and T24/83 are phenotypically similar. Specifically, we compared the expression of $\mathrm{G}$ protein-coupled receptors on these cell lines and the ability of these receptors to initiate functional responses typical of endothelial cells. We have also compared mitogenic responses of ECV304 and T24/83 with other endothelial cultures.

Significantly, karyotypic analysis provided unequivocal evidence that ECV304 and T24/83 are genetically identical. To facilitate additional phenotypic comparison, we analyzed the pharmacology of P2Y receptors, an important class of $\mathrm{G}$ protein-coupled receptors activated by extracellular nucleotides. Indeed, numerous studies have reported expression of P2Y receptors on vascular endothelium (for reviews see Boarder et al, 1995; Boarder and Hourani, 1998) and ECV304 cells (Conant et al, 1998; Howl et al, 1998). P2Y receptors typically activate phospholipase $\mathrm{C}$ and stimulate production of endothelium-dependent vasodilators (Bowden et al, 1995; Brown et al, 1996; Mitchell et al, 1990; 1992). Our studies indicated that ECV304 and T24/83 cells express a single sub-type of P2Y receptor, $\mathrm{P}_{2} \mathrm{Y}_{2}$. These findings support our previous report (Howl et al, 1998) in which responses were observed to ATP, UTP, and ADP, but not 2MeSATP; however, these findings are in contrast to a recent report in which calcium mobilization was observed in response to 2MeSATP (Conant et al, 1998). One possible explanation for these conflicting results is a passage-specific effect resulting in a loss of $\mathrm{P}_{2} \mathrm{Y}_{1}$ receptor expression. As reported (Conant et al, 1998), studies with individual cells indicated that responses to 2MeSATP were observed only in sub-populations of ECV304 cells, whereas responses to uridine nucleotides were present in all cells. The results obtained in inositol phosphate assays are supported by our experiments measuring the mobilization of $\left[\mathrm{Ca}^{2+}\right]_{i}$ in which responses were obtained for ATP and UTP but 
A

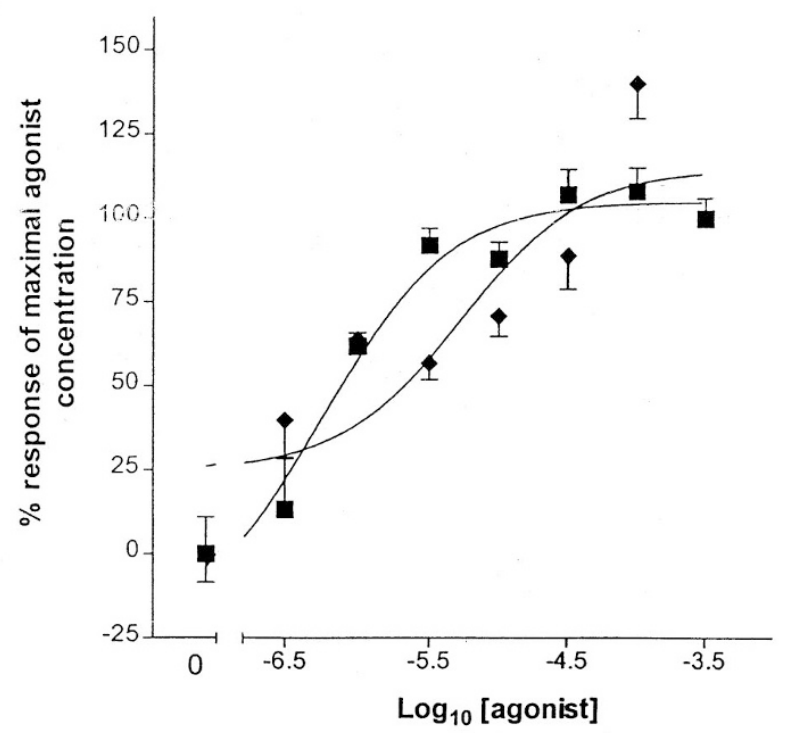

B

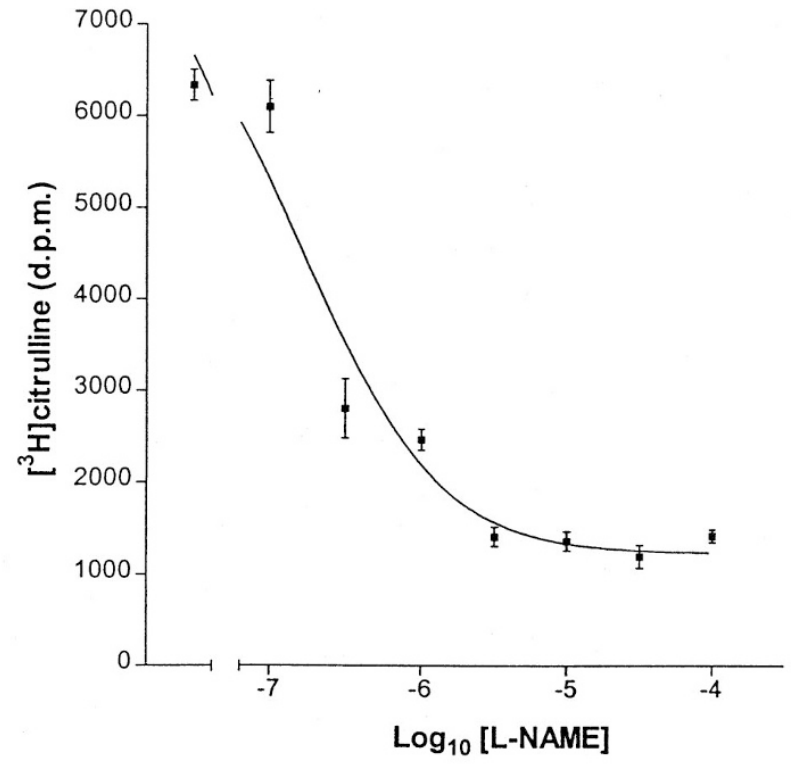

C

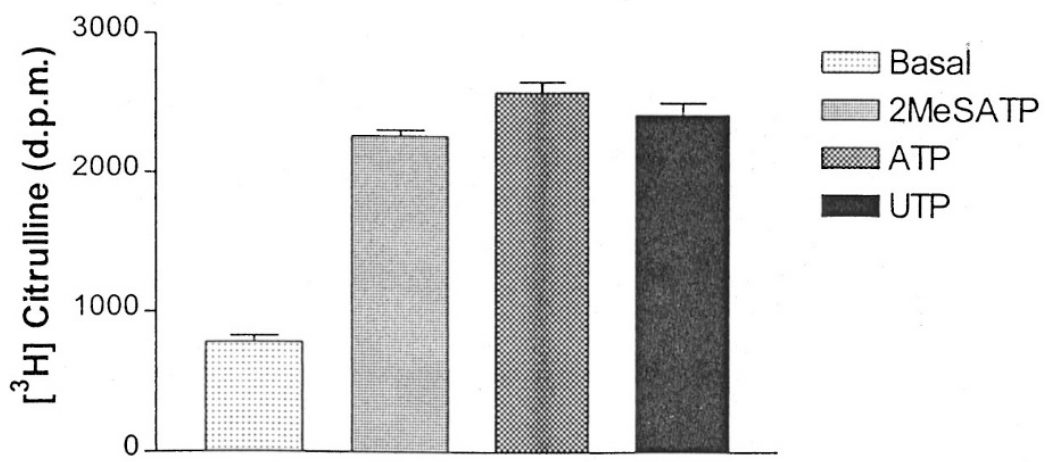

\section{Figure 4.}

Results show the release of nitric oxide as indicated by the accumulation of $\left[{ }^{3} \mathrm{H}\right.$ ]citrulline in cell extracts. $A$ shows the dose response to ATP and UTP in ECV304 cells. Data are mean results \pm SEM from three separate experiments. $B$ shows that high basal turnover of nitric oxide in ECV304 cells can be dose-dependently inhibited by the arginine analog, L-NAME. Data are mean results \pm SEM from 1 representative experiment of three. $C$ shows low basal turnover of nitric oxide production and agonist stimulations in BAE cells. Data are mean results \pm SEM from 5 separate experiments. 


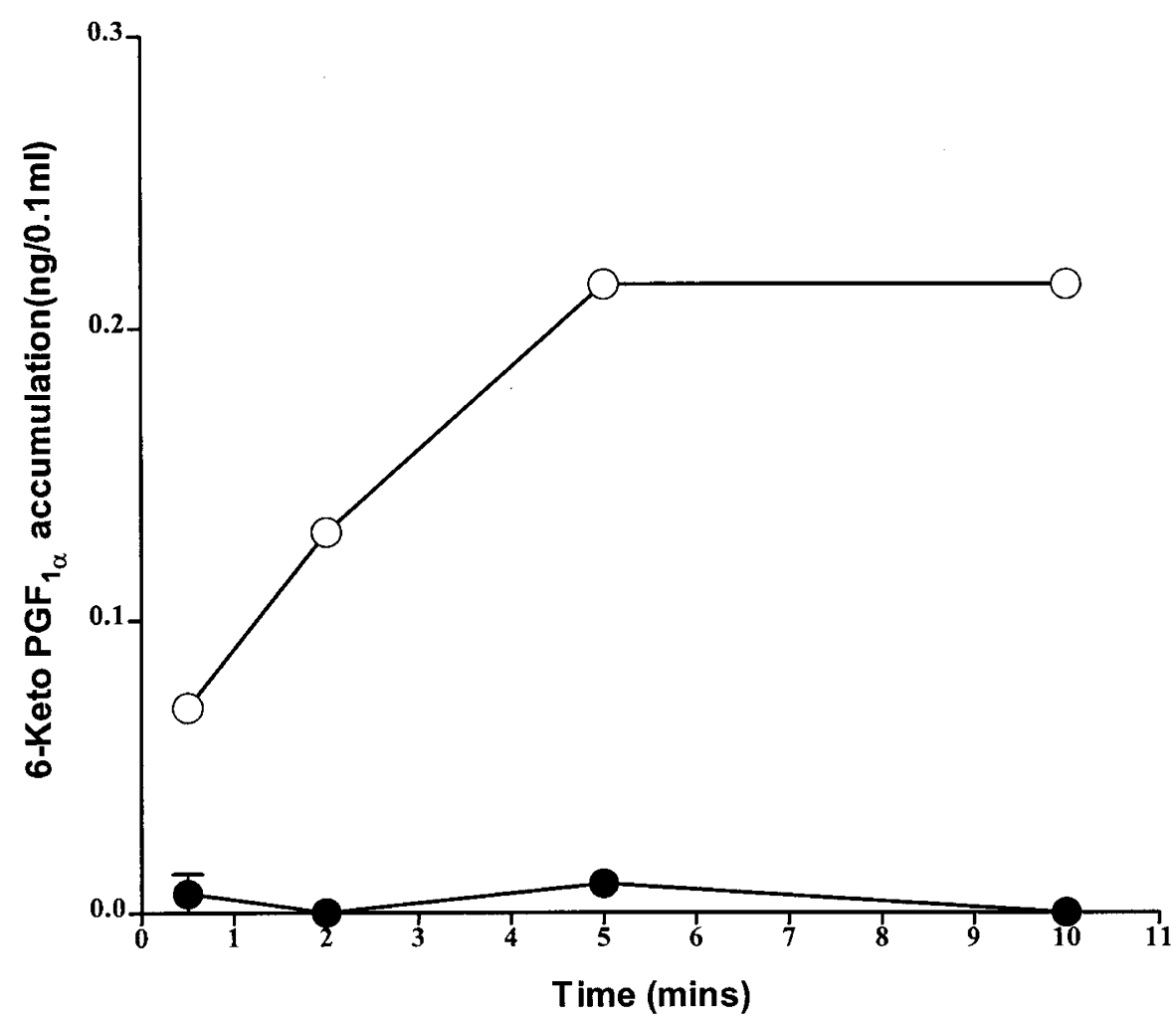

Figure 5 .

A time course for UTP $(300 \mu \mathrm{m})$-mediated accumulation of 6-keto PGF I $_{1 \alpha}$ in ECV304 cells $(\bullet)$ and BAE cells $(\bigcirc)$. Data are mean results \pm SEM from three separate experiments performed in triplicate.

Table 2. Comparative Studies of Thymidine Incorporation

\begin{tabular}{lccc}
\hline Cell line & $\begin{array}{c}24 \mathrm{~h} \\
\text { serum-free }\end{array}$ & $\begin{array}{c}48 \mathrm{~h} \\
\text { serum-free }\end{array}$ & $\begin{array}{c}72 \mathrm{~h} \\
\text { serum-free }\end{array}$ \\
\hline ECV304 & $0.93 \pm 0.10$ & $0.89 \pm 0.22$ & $0.70 \pm 0.12$ \\
T24/83 & $2.78 \pm 0.33$ & $1.57 \pm 0.14$ & $1.68 \pm 0.23$ \\
PAE & $38.10 \pm 8.13$ & ND & ND \\
BAE & $107.7 \pm 20.9$ & ND & ND \\
\hline
\end{tabular}

Cells were incubated in serum-free medium for the times indicated, followed by the addition of serum for 21 hours. Incorporation of tritium into the cells is expressed as increase over basal (serum-free) levels. Data are mean values \pm SEM from separate experiments, each performed in triplicate. $\mathrm{ND}$, not determined.

not 2MeSATP or UDP. These comparative data of $\mathrm{Ca}^{2+}$ mobilization would also preclude the possibility of a P2Y $\mathrm{Y}_{1}$ receptor linked to the mobilization of $\left[\mathrm{Ca}^{2+}\right]_{i}$ in the absence of any detectable PLC response, as was recently reported in microvascular endothelial cells (Albert et al, 1997).

Our previous report demonstrated the presence of receptors that are coupled to adenylate cyclase in ECV304 (Howl et al, 1998). Therefore we compared the effects of various agonists on cAMP levels in both ECV304 and T24/83 cells. Significantly, similar responses to adrenaline, NECA, and calcitonin were observed in both cell lines. There was no effect of either ATP or UTP on basal or agonist-stimulated levels of CAMP. Therefore it is unlikely that ECV304 or
T24/83 cells possess a P2Y receptor linked to inhibition of adenylate cyclase.

To further examine functional responses in ECV304 cells, we determined the ability of purinergic agonists to stimulate the production of nitric oxide and prostacyclin, because it is well established that endothelial $\mathrm{P} 2 \mathrm{Y}$ receptors are linked to the production of these vasoactive substances (Bowden et al, 1995; Brown et al, 1996; Mitchell et al, 1990; 1992). Both ATP and UTP dose-dependently stimulated the activation of NOS in ECV304. The time course of this activation was maximal by 5 minutes (not shown) and each agonist produced an approximate 2-fold increase over basal levels. One observation arising from these experiments was a very high basal accumulation of $\left[{ }^{3} \mathrm{H}\right]$ citrulline that could be dosedependently inhibited by the arginine analog L-NAME. The extent of the inhibition by L-NAME was variable, with a mean $I_{50}$ for L-NAME of $7.2 \pm 2.0 \times 10^{-8} \mathrm{M}$. This high basal turnover may account for the relatively small stimulations observed with agonists, because the system may be substantially activated in the absence of added agonist. In contrast to these findings, similar experiments performed using BAE cells showed a very low accumulation of citrulline under basal conditions, with an approximate 5-fold response being observed in the presence of purinergic agonists. The precise nature of the high basal turnover observed in ECV304 remains to be elucidated. However, a study using T24/83 cells also reported a high turnover of NOS under basal conditions, which comprised both calcium-dependent and 
calcium-independent components (Morcos et al, 1999). It is not clear from our studies which isoform(s) of NOS give rise to the high basal accumulation of citrulline, but the recent observation that ECV304 cells are devoid of the endothelial form of NOS is highly significant in the light of these findings (Sowa et al, 1999). In this context, it is also noteworthy that a study by Kojima et al (1999) reported high levels of NOS in colon carcinoma tissue when compared with levels in noncarcinoma tissue.

The ability of UTP to stimulate production of $\mathrm{PGI}_{2}$ was determined by radioimmunoassay of this stable breakdown product 6-keto $\mathrm{PGF}_{1 \alpha}$. Surprisingly, these experiments revealed that $100 \mu \mathrm{M}$ UTP was unable to stimulate production of 6-keto $\mathrm{PGF}_{1 \alpha}$ at time points up to 30 minutes. This is in contrast to parallel experiments performed in BAE cells and our previous report (Bowden et al, 1995) in which a substantial increase in $\mathrm{PGI}_{2}$ products over basal levels was observed, being maximal at approximately 5 minutes. This lack of response in ECV304 cells further indicates these cells are "atypical" in terms of primary endothelial cultures.

Measurement of thymidine incorporation into cells is widely used as an index of DNA synthesis/mitogenesis. Addition of serum to PAE and BAE cells markedly increased the rate of DNA synthesis. In contrast, the addition of serum had little or no effect on DNA synthesis in either ECV304 or T24/83 cells. Basal levels of thymidine incorporation were significantly higher in ECV304 and T24/83 cells than in either PAE or BAE cells and increased with up to 72 hours incubation in serum-free medium. Thus it appears that removal of serum from ECV304 or T24/83 cells is not sufficient to stop cell division, and addition of serum to the medium does not enhance the rate of incorporation of tritium into these cells. These data provide further evidence that ECV304 cells more closely resemble a metastatic cell line rather than an endothelial cell line.

In conclusion, our results show that both ECV304 and T24/83 cells express a receptor of the $P 2 Y_{2}$ subtype, but do not respond to the $\mathrm{P}_{2} \mathrm{Y}_{1}$ agonist 2MeSATP. P2Y 2 receptors, through activation of PLC and mobilization of intracellular calcium, stimulate production of nitric oxide but not prostacyclin. ECV304 and T24/83 cells also express similar receptors positively coupled to adenylate cyclase. The expression of a calcitonin receptor further supports a nonendothelial origin of ECV304. Thus, this report provides important new information demonstrating that ECV304 cells display a number of phenotypic characteristics that differ from those expected of vascular endothelium but are similar to T24/83 cells. We conclude that ECV304 is useful for the study of G protein-coupled receptors but is clearly not of HUVEC origin. Therefore these cells are not a suitable model for the study of endothelial cell function.

\section{Materials and Methods}

The following materials were supplied by Sigma (Sigma Chemical, Poole, Dorset, United Kingdom): ATP, UTP, ADP, UDP, 2MeSATP, calcitonin, NECA, and adrenaline.

\section{Cell Culture}

ECV304 and T24/83 cells were maintained in M199 medium with glutamax (Gibco BRL, Gaithersburg, Maryland), supplemented with $10 \%$ fetal bovine serum (FBS), $100 \mathrm{U} / \mathrm{ml}$ penicillin, and $100 \mu \mathrm{g} / \mathrm{ml}$ streptomycin. BAE cells were cultured in minimal essential medium with D-valine (Gibco) supplemented with 10\% FBS, $100 \mathrm{U} / \mathrm{ml}$ penicillin, $100 \mu \mathrm{g} / \mathrm{ml}$ streptomycin, and $2 \mathrm{~mm}$ L-glutamine. PAE cells were cultured in Nut.Mix.F12 (HAM) with glutamax (Gibco) supplemented with $10 \%$ FBS.

\section{DNA Fingerprinting}

Cells were grown to confluence in $175 \mathrm{~cm}^{2}$ flasks, the media was removed and cells were washed in a balanced salt solution (BSS) of the following composition (in mm): $\mathrm{NaCl} 125 ; \mathrm{KCl} 5.4 ; \mathrm{NaHCO}_{3}$ 16.2; $\mathrm{N}$-2-hydroxylpiperazine-N-2-ethanesulphonic acid (HEPES) 15; $\mathrm{NaH}_{2} \mathrm{PO}_{4} 1 ; \mathrm{MgSO}_{4} 0.8 ; \mathrm{CaCl}_{2}$ 1.8; and glucose $5.5 ; \mathrm{pH}$ 7.4. Cells were lysed in $0.5 \mathrm{ml}$ of lysis buffer A (100 mм NaCl; 1 mм EDTA; 20 mм EDTA; 20 $\mathrm{mm}$ Tris) and $0.5 \mathrm{ml}$ of lysis buffer $\mathrm{B}$ (1\% SDS; $10 \mathrm{~mm}$ Tris; 0.5 mм EDTA; $\mathrm{pH}$ 8.0). Proteinase $\mathrm{K}$ was added to the cell lysates at a final concentration of $300 \mu \mathrm{g} / \mathrm{ml}$. Samples were incubated overnight at $55^{\circ} \mathrm{C}$ and phenol chloroform extracted DNA digested with $1 \mathrm{U} / \mu \mathrm{l}$ Alul (Gibco). Fragments were subjected to electrophoresis through a $20-\mathrm{cm}$ long $0.8 \%$ agarose gel and transferred by blotting to nylon membrane (Amersham Corporation, Paisley, United Kingdom). The membrane was exposed to a single-stranded ${ }^{32} \mathrm{P}$-labeled hybridization probe, 33.15 (Jeffreys et al, 1985) overnight and washed before exposure to X-ray film.

\section{$\left[{ }^{3} \mathrm{H}\right]$-Inositol Labeling and Assay of $\left[{ }^{3} \mathrm{H}\right]-$ Inositol Polyphosphates}

Cells were labeled for 24 hours with $0.5 \mu \mathrm{Ci}\left[{ }^{3} \mathrm{H}\right]$-myoinositol (17.0 Ci/mmol) (Amersham) per well in BSS. Lithium chloride was added to cells at a final concentration of $10 \mathrm{~mm} 10$ minutes before addition of agonists. The treatment of dinucleotides with hexokinase to remove trinucleotide contamination was performed according to the method of Harden et al (1997). Stimulations were terminated by removal of BSS and immediate addition of ice-cold $0.5 \mathrm{M}$ trichloroacetic acid (TCA). Cells were incubated on ice for 1 hour and acid extracts washed with $3 \times 4$ volumes of watersaturated diethyl ether and buffered to $\mathrm{pH} 7$ with $0.6 \mathrm{M}$ $\mathrm{NaHCO}_{3}$. A fraction containing $\left[{ }^{3} \mathrm{H}\right] \mathrm{IP} \mathrm{P}_{1}-\mathrm{IP}_{4}$ was recovered from $1 \mathrm{ml}$ Dowex $1 \times 8$ to 400 (Sigma) columns, by extraction with $1 \mathrm{~m}$ ammonium formate.

\section{Fluorometric Analysis of $\left[\mathrm{Ca}^{2+}\right]_{i}$}

Cells were incubated in $2.5 \mu \mathrm{M}$ Fura2 AM in BSS 30 minutes at room temperature, centrifuged, and the supernatant discarded to remove extracellular Fura2 AM. These cells were resuspended in BSS with $30 \mathrm{~mm}$ EGTA to remove extracellular calcium. Measurement of intracellular calcium was performed using a lumi- 
nescence spectrometer model LS-50B (Perkin-Elmer Cetus, Norwalk, Connecticut). Fura 2 was excited at $340 \mathrm{~nm}$ and emissions were recorded at $510 \mathrm{~nm}$.

\section{Measurement of cAMP Production}

For cAMP assays (Howl et al, 1998), confluent cells in 24-well plates were washed twice with warm medium and incubated for 15 minutes at $37^{\circ} \mathrm{C}$ in BSS containing $0.5 \mathrm{~mm}$ IBMX. Agonists were added for a further period of 15 or 30 minutes. Reactions were terminated by washing cells twice in ice-cold $70 \%$ ethanol. Cytoplasmic contents were extracted by scraping cells in ice-cold $70 \%$ (v/v) ethanol $(0.5 \mathrm{ml} /$ well). Samples were stored on ice for 60 minutes and supernatants separated from cell debris by centrifugation. Pelleted material was extracted further and the combined supernatants dried under vacuum. Cytoplasmic extracts were dissolved in buffer (50 mM Tris, 4 mm EDTA, pH 7.5) and CAMP measured using Biotrak assay kits according to manufacturers instructions.

\section{${ }^{3}$ H]Thymidine Incorporation into DNA}

Subconfluent cells were grown in serum free M199 medium (Gibco) in 6-well plates. Medium was replaced after 24,48 , and 72 hours with M199 containing 10\% FBS. After 21 hours, $1 \mu \mathrm{Ci}\left[{ }^{3} \mathrm{H}\right]$ thymidine (51.0 Ci/mmol) (Amersham) was added to each well. Three hours later, the stimulating media was removed and cells were washed twice in $4 \mathrm{ml}$ with PBS then once in $2 \mathrm{ml}$ with $10 \%$ TCA. Cells were lysed in $1 \mathrm{ml}$ $0.2 \mathrm{M} \mathrm{NaOH}$, and radioactivity in lysates was determined by liquid scintillation spectroscopy.

\section{Measurement of Nitric Oxide Synthase Activity}

The ability of agonists to stimulate the conversion of $\left[{ }^{3} \mathrm{H}\right]$ arginine to $\left[{ }^{3} \mathrm{H}\right]$ citrulline was used as an index of nitric oxide synthase activity, as previously described (Brown et al, 1996). Cells were grown to confluence in 24-well plates, then washed twice in $1 \mathrm{ml}$ in BSS at $37^{\circ} \mathrm{C}$ prior to labeling with $0.6 \mu \mathrm{Ci} \mathrm{L}-[2,3,4,5-$ ${ }^{3} \mathrm{H}$ ]arginine $(54.0 \mathrm{Ci} / \mathrm{mmol})$ (Amersham) per well in BSS for 10 minutes. Cells were stimulated for 5 minutes and incubations terminated by washing three times in $1 \mathrm{ml}$ with ice-cold BSS. The BSS was aspirated and cells were incubated on ice in $0.5 \mathrm{M}$ TCA for 2 hours. Acid extracts were washed three times in 4 volumes of diethyl ether and buffered to $\mathrm{pH} 6$ with 1.5 $\mathrm{ml} 20 \mathrm{~mm}$ HEPES $\mathrm{pH}$ 6. The extracts were passed through $1 \mathrm{ml}$ Dowex 50WX8-400 columns and the $\left[{ }^{3} \mathrm{H}\right]$ citrulline fraction eluted with $4 \mathrm{ml}$ of distilled water.

\section{Measurement of 6-Keto PGF ${ }_{1 \alpha}$ Release}

Measurement of the accumulation of 6-keto $\mathrm{PGF}_{1 \alpha}$ in the supernatant of stimulated cells was used as an index of $\mathrm{PGI}_{2}$ release. Cells were grown to confluence in 24-well plates, the medium was aspirated and cells were washed twice with BSS, and incubated for 10 minutes in $1 \mathrm{ml} \mathrm{BSS}$ at $37^{\circ} \mathrm{C}$. Agonist stimulations were terminated by the removal of the supernatants to polypropylene tubes and stored at $-20^{\circ} \mathrm{C}$ until required. Radioimmunoassay for 6-keto $\mathrm{PGF}_{1 \alpha}$ used $25 \mu \mathrm{l}$ of 6-keto $\left[5,6,9,11,12,14,15-{ }^{3} \mathrm{H}\right]-\mathrm{PGF}_{1 \alpha}(177 \mathrm{Ci} / \mathrm{mmol})(\mathrm{Am}-$ ersham), $25 \mu$ l of polyclonal anti-6-keto $\mathrm{PGF}_{1 \alpha}$ at a 1:5 dilution, and $50 \mu \mathrm{l}$ of sample or standard. Samples and standards were incubated overnight at $4^{\circ} \mathrm{C}$ and dextran-coated charcoal was used to separate bound 6-keto $\mathrm{PGF}_{1 \alpha}$ from free. After centrifugation, the amount of 6-keto $\left[5,6,9,11,12,14,15,{ }^{3} \mathrm{H}\right]-\mathrm{PGF}_{1 \alpha}$ in the supernatant was measured.

\section{Acknowledgements}

The authors would like to thank Ms. Ruth Barber, Genetics Department, University of Leicester, for her excellent technical assistance.

\section{References}

Albert JL, Boyle JP, Roberts JA, Challiss J, Gubby SE, and Boarder MR (1997). Regulation of brain capillary endothelial cells by P2Y receptors coupled to $\mathrm{Ca}^{2+}$, phospholipase $\mathrm{C}$ and mitogen-activated protein kinase. $\mathrm{Br} \mathrm{J}$ Pharmacol 122: 935-941.

Boarder MR, Weisman GA, Turner JT, and Wilkinson GF (1995). G protein-coupled $P_{2}$ purinoceptors: From molecular biology to functional responses. TiPS 16:133-139.

Boarder MR and Hourani SMO (1998). The regulation of vascular function by $\mathrm{P}_{2}$ receptors: Multiple sites and multiple receptors. TiPS 19:99-107.

Bowden A, Patel V, Brown C, and Boarder MR (1995). Evidence for requirement of tyrosine phosphorylation in endothelial P2Y- and P2U-purinoceptor stimulation of prostacyclin release. Br J Pharmacol 116:2563-2568.

Brown CA, Patel V, Wilkinson G, and Boarder MR (1996). $P_{2}$ purinoceptor-stimulated conversion of arginine to citrulline in bovine endothelial cells is reduced by inhibition of protein kinase C. Biochem Pharmacol 52:1849-1854.

Conant AR, Fisher MJ, Mclennan AG, and Simpson AWM (1998). Characterization of the P2 receptors on the human umbilical vein endothelial cell line ECV304. Br J Pharmacol 125:357-364.

Gallery EDM, Rowe J, Schreiber L, and Jackson CJ (1991). Isolation and purification of microvascular endothelium from human decidual tissue in the late phase of pregnancy. Am $\mathrm{J}$ Obs and Gynecol 165(1):191-196.

Harden TK, Lazarowski ER, and Boucher RC (1997). Release, metabolism and interconversion of adenine and uridine nucleotides: implications for $\mathrm{G}$ protein-coupled P2 receptor agonist selectivity. TiPS 18:43-46.

Howl J, Mondszein RM, and Wheatley M (1998). Characterization of $\mathrm{G}$ protein-coupled receptors expressed by ECV304 human endothelial cells. Endothelium 6:23-32.

Hughes SE (1996). Functional characterization of the spontaneously transformed human umbilical vein endothelial cell line ECV304: Use in an in vitro model of angiogenesis. Exp Cell Res 225:171-185.

Jeffreys AJ, Wilson V, and Thein SW (1985). Hypervariable "minisatellite" regions in human DNA. Nature 314:67-73. 
Kojima M, Morisaki T, Tsukahara Y, Uchiyama A, Matsunari Y, Mibu R, and Tanaka M (1999). Nitric oxide synthase expression and nitric oxide production in human colon carcinoma tissue. J Surg Oncol 70(4):222-229.

Mitchell JA, Hecker M, and Vane JR (1990). The generation of $\mathrm{L}$-arginine in endothelial cells is linked to the release of endothelium-derived relaxing factor and prostacyclin. Eur J Pharmacol 176:253-254.

Mitchell JA, De Nucci G, Warner TD, and Vane JR (1992). Different patterns of release of endothelium-derived relaxing factor and prostacyclin. Br J Pharmacol 105:485-489.

Morcos E, Jansson OT, Adolfson J, Kratz G, and Wiklund NP (1999). Endogenously formed nitric oxide modulates cell growth in bladder cancer cell lines. Urology 53(6):1252-1257.

Motte S, Pirotton S, and Boeynaems JM (1993). Heterogeneity of ATP receptors in aortic endothelial cells. Involvement of $\mathrm{P}_{2 Y}$ and $\mathrm{P}_{2 \mathrm{U}}$ receptors in inositol phosphate response. Circulation Res 72(3):504-510.

Sowa G, Liu JW, Papapetropoulos A, Rexhaffner M, Hughes TE, and Sessa WC (1999). Trafficking of endothelial nitricoxide synthase in living cells: Quantitative evidence supporting the role of palmitoylation as a kinetic trapping mechanism limiting membrane diffusion. J Biol Chem 274(32):2252422531.

Spatz M, Kawai N, Merkel N, Bembry J, and McCarron RM (1997). Functional properties of cultured endothelial cells derived from large microvessels of human brain. Am J Physiol-Cell Physiol 41(1):C231-C239.
Takahashi K, Sawasaki Y, Hata J-I, Mukai K, and Goto T (1990). Spontaneous transformation and immortalization of human endothelial cells. In Vitro Cell Dev Biol 25:263-274.

Takahashi K and Sawasaki Y (1992). Rare spontaneously transformed human endothelial cell line provides useful research tool. In Vitro Cell Dev Biol 28A:380-382.

Tokunaga $O$ and Watanabe $T$ (1987). Atherosclerosis and endothelium: A simple method of endothelia-cell culture from human atherosclerotic aorta. Acta Pathologica Japonica 37(4):527-536.

Weis JR, Sun B, and Rodgers GM (1991). Improved method of umbilical arterial endothelial-cell culture. Thrombosis Res 61(2):171-173.

Wilkinson GF, McKechnie K, Dainty IA, and Boarder MR (1994). $P_{2 Y}$-purinoceptor and nucleotide receptor-induced relaxation of precontracted bovine aortic collateral artery rings: Differential sensitivity to suramin and indomethacin. J Pharmacol Exp Ther 268:881-887.

Williams SK (1987). In Microvascular perfusion and transport in health and disease McDonagh PF, editor. Basel: Karger, 204-245. 